Skin Pharmacol 1990;3:I-V

\title{
Contents Vol. 3, 1990
}

\section{No. 1 Review}

Dithranol: A Review of the Mechanism of Action in the Treatment of Psoriasis vulgaris

Kemény, L.; Ruzicka, T.; Braun-Falco, $0 \quad 1$

Original Research Articles

Topical Delivery of Ciclosporin: Evaluation of Various Formulations Using in vitro Diffu sion Studies in Hairless Mouse Skin

Egbaria, K.; Ramachandran, C; Weiner, N 21

Cellular and Biochemical Characterization of the Anti-Inflammatory Effects of DuP 654 in the Arachidonic Acid Murine Skin Inflammation Model

Harris, R.R.; Mackin, W.M.; Batt, D.G.; Rakich, S.M.; Collins, R.J.; Bruin, E.M.;

Ackerman, N.R 29

Experimental Evidence for Amide Hydrolysis of Indomethacin in Rabbit Skin

Behrendt, H.; Korting, H.C 41

Short Communication

Effect of Leukotriene B5 on the Accumulation of Polymophonuclear Leukocytes in

Unstimulated and Leukotriene B4-Stimulated Human Skin

Wozel, G.; Chang, A.; Barth, J.; Happle, R.; van de Kerkhof, P.C.M

Abstracts

AAPS Topical Drug Products Workshop

March 26-28, 1990, Arlington, Va., USA

No. 2 Reconstructed Human Skin

Editorial 65

Introductory Remarks

Prunieras, M 66

Human Epidermis Reconstructed on Dermal Substrates in vitro: An Alternative to Animals in Skin Pharmacology

Régnier, M.; Asselineau, D.; Lenoir, M.C 70

Evidence for Autoregulatíon of Cell Division and Cell Transit in Keratinocytes Grown on

Collagen at an Air-Liquid Interface

MacCallum, D.K.; Lillie, J.H 86

Architecture of Reconstructed Epidermis on Collagen Lattices Varies according to the

Method Used: A Comparative Study

Lenoir, M.C; Bernard, B.A 97

IV Contents

Characterization of Skin Reconstructed on a Chitosan-Cross-Linked Collagen-Glycosaminoglycan Matrix

Shahabeddin, L.; Berthod, F.; Damour, O.; Collombel, C 107

Pseudoepidermis, Constructed in vitro, for Use in Toxicological and Pharmacological

Studies 
Scavarelli-Karantsavelos, R.M.; Zaman Saroya, S.; Vaughan, F.L.; Bernstein, LA. . 115

Nitroglycerin and Sucrose Permeability as Quality Markers for Reconstructed Human Epidermis

Ponec, M.; Wauben-Penris, P.J.J.; Burger, A.; Kempenaar, J.; Boddé, H.E 126

Reconstructed Skin from Cultured Human Keratinocytes and Fibroblasts on a Collagen-

Glycosaminoglycan Biopolymer Substrate

Boyce, S.; Michel, S.; Reichert, U.; Shroot, B.; Schmidt, R 136

Reconstruction of the Human Skin Equivalent in vitro: A New Tool for Skin Biology

Dubertret, L 144

No. 3 Original Research Articles

Effect of Ciclosporin A on Epidermal Keratinocytes in vitro: Lack of a Direct Effect on

Calmodulin

Fairley, J.A.; Fung, P.D.; Ewing, N.M

149

Comparative Study of Antiseptic Toxicity on Basal Keratinocytes, Transformed Human

Keratinocytes and Fibroblasts

Tatnall, F.M.; Leigh, I.M.; Gibson, J.R 157

Effect of Tiacrilast, a Mast Cell Mediator-Release Inhibitor, on Murine Experimental Contact

Dermatitis

Csatò, M.; Judák, R.; Bozóky, B.; Czarnetzki, B.M 164

Detection of DNA Adducts in Skin Biopsies of Coal Tar-Treated Psoriasis Patients: Immu-

nofluorescence and 32P Postlabeling

Zhang, Y.J.; Li, Y.; DeLeo, V.A.; Santella, R.M 171

High Capacity of Human Skin for N-Acetylation of Arylamines

Kawakubo, Y.; Yamazoe, Y.; Kato, R.; Nishikawa, T 180

Editorial Note 185

Abstracts

7th Annual Meeting of the Skin Pharmacology Society October 30-31, 1990, Hiroshima, Japan

Oral Presentations 186

Posters 199

No. 4 Original Research Articles

Irritant Patch Testing: Penetration of Sodium Lauryl Sulphate into Human Skin

Agner, T.; Fullerton, A.; Broby-Johansen, U.; Batsberg, W 213

Noninvasive Transdermal Chemical Collection. I. In vitro Adsorption Characteristics of

Gel/Charcoal Matrices

Bradley, C.R.; Conner, D.P.; Peck, C.C 218

Noninvasive Transdermal Chemical Collection. II. In vitro and in vivo Skin Permeability

Studies

Bradley, C.R.; Almirez, R.G.; Conner, D.P.; Rhyne, P.R.; Peck, C.C 227

Contents V

An Ultrastructural Study of Transcutaneous Migration of Polymorphonuclear Leukocytes following Application of Leukotriene B4

Paulissen, M.; Copius Peereboom-Stegeman, J.H.J.; van de Kerkhof, P.C.M 236

Objective Assessment of Topical Anti-Inflammatory Drug Activity on Experimentally

Induced Nickel Contact Dermatitis: Comparison between Visual Scoring, Colorimetry,

Laser Doppler Velocimetry and Transepidermal Water Loss

Queille-Roussel, C; Duteil, L.; Padilla, J.-M.; Poncet, M.; Czernielewski, J248

Differentiation of F9 Embryonal Carcinoma Cells by Synthetic Retinoids: Amplitude of 
Plasminogen Activator Production Does Not Depend on Retinoid Potency or Affinity for F9 Nuclear Retinoic Acid Receptors

Bailly, J.; Delescluse, C; Bernardon, J.M.; Charpentier, B.; Martin, B.; Pilgrim, W.R.;

Shroot, B.; Darmon, M

256

Short Communication

Effect of Glycyrrhizin on Pain and HLA-DR Antigen Expression on CD8-Positive Cells in Peripheral Blood of Herpes zoster Patients in Comparison with Other Antiviral Agents

Aikawa, Y.; Yoshiike, T.; Ogawa, H 268

Announcements

272

Acknowledgement to Reviewers

Author Index 274

Subject Index $\quad 277$ 